\title{
Evaluation of the Structural Performance of Lateritic Soil Stabilized with Cassava Peel Ash (CPA) and Cement
}

\author{
Olutaiwo A.O., Adanikin Ariyo \\ Department of Civil and Environmental Engineering \\ University of Lagos, Akoka. Lagos, Nigeria \\ adewaleolutaiwo@gmail.com
}

\begin{abstract}
This study presents the result of experimental investigation on the evaluation of the effects of Cassava Peel Ash (CPA) on the index and structural properties of lateritic soil of A-7-5 (AASHTO Classification) and SP soil (USCS classification) respectively. The study was in two phases, firstly with the addition of CPA only by weight of dry soil and secondly with the addition of $5 \%$ cement with the CPA by weight of dry soil. The CPA additions were performed using 0, 2, 4, 6, 8 and 10\% increment by weight of dry soil thoroughly mixed. The results of the treated soil showed that the index properties: plastic limit and the maximum dry density (MDD) decreased as the CPA addition increased whereas the liquid limit, plasticity index, Optimum Moisture Content (OMC) and California Bearing Ratio (CBR) increased as the CPA content increased. It was also discovered that the Unconfined Compressive Strength (UCS) increased up to 4\% of CPA addition after which was a reduction. This implies that CPA possesses the potential for use in the modification/ stabilization of lateritic soils. Thus the use of CPA in road construction works can be said to have two major advantages - as an effective agricultural waste management and the improvement of road construction soils for better road performance.
\end{abstract}

Keywords: Cassava Peel Ash (CPA), Ordinary Portland cement, Stabilization, Laterite Soil, OMC, MDD, $C B R, U C S$.

\section{INTRODUCTION}

The most available soils may lack some required engineering properties to bear the expected superimposed loads, so improvements have to be made to make these soils better through soil modification /stabilization.

The volume of wastes generated in the world has also increased over the years and agricultural wastes constitute a major component. Nigeria, being the highest producer of cassava in Africa, has the highest volume of Cassava Peel (Food and Agricultural Organization FAO, 2013). One of the most attractive options of managing such wastes and minimizing their negative environmental effects is to look into the possibility of waste minimization and re-utilization. This will also help to reduce the overdependence on conventional cement for soil stabilization, which will then produce economic advantages.

\section{LITERATURE REVIEW}

Lateritic soils form a group comprising a wide variety of red, brown, and yellow, fine-grained residual soils of light texture as well as nodular gravels and cemented soils (Lambe and Whitman, 1979). Abundance of these soils and their favourable engineering properties make them useful as a construction or foundation material for roads, airfields, low-cost housing and compacted fill in earth embankments. Garber and Hoel (2000) describe soil stabilization as the treatment of natural soil to improve its engineering properties.

Pozzolans are defined as materials, which though not cementitious in themselves, contain constituents which will combine with alkalis at ordinary temperature in the presence of water to form insoluble compounds possessing cementitious properties (en.wikipedia.org/wiki/Pozzolan). Nigerian cassava production is by far the largest in the world, a third more than the production in Brazil and almost double the production of Indonesia and Thailand (FAO, 2013). Cassava peel is a by-product of cassava processing either for domestic consumption or industrial uses. Adesanya et al., (2008) 
reported that cassava peels constitute between $20-35 \%$ of the weight of the tuber, especially in the case of hand peeling which is the predominant method used in Nigeria.

Previous research works on agricultural wastes as it affects soil stabilization include: Soil stabilization using some pozzolanic industrial and agricultural products (Chmeisse,1992); Structural Strength Characteristics of Cement-Cassava Peel Ash Blended Concrete (Salau M.A, 2012); Cassava Peel Ash Stabilized Lateritic Soil as Highway Pavement Material (Edeh, J. 2014); Effect of Coconut Husk Ash on the Geotechnical Properties of Poor Lateritic Soil (Oluremi, 2012);Characteristics of Bamboo Leaf Ash Stabilization on Lateritic Soil (Olugbenga, 2010).

\section{Study Methodology}

Cassava peels used in this study were collected as refuse from a local processing factory in Emure, Ekiti State of Nigeria (Coordinates $7.4500^{\circ} \mathrm{N}, 5.4667^{\circ} \mathrm{E}$ ).

The peels were first dried in open air and burnt to ash in an electric furnace (Carbolite GPC 12/65) at $750^{\circ} \mathrm{C}$ for 90 minutes. The clinker was grinded to fine powder and passed through the $150 \mu \mathrm{m}$ sieve. The Lateritic soil was obtained from borrow pit located at KM 48 Lagos-Ibadan expressways, Redemption camp, Ogun State. Nigeria. The soil samples were taken at depths of $2 \mathrm{~m}$ from the natural ground surface. Plates 1-4 show the stages of sourcing and conversion of the cassava peel to ash.

\subsection{Tests on Cassava Peel Ash}

Chemical tests were carried out on the CPA samples to determine their chemical compositions. The results are shown in Table 1.

\subsection{Tests on Soil Sample}

The following tests were carried out on the tested soil sample:

- The Atterberg limits, used to distinguish between silty, sandy and clayey soils.

- Compaction test, carried out to determine the Optimum Moisture Content (OMC) and the Maximum Dry Density (MDD) of CPA-added sample (0\%-10\%)

- California Bearing Ratio, used to determine the bearing capacity of both the soil sample alone and the CPA-added soil sample. The tests were carried out on the sample in the soaked and unsoaked states.

- Unconfined Compressive Strength Test, used to obtain the shear strength parameters of cohesive (fine grained) soils either in undisturbed or remolded state using a triaxial machine.

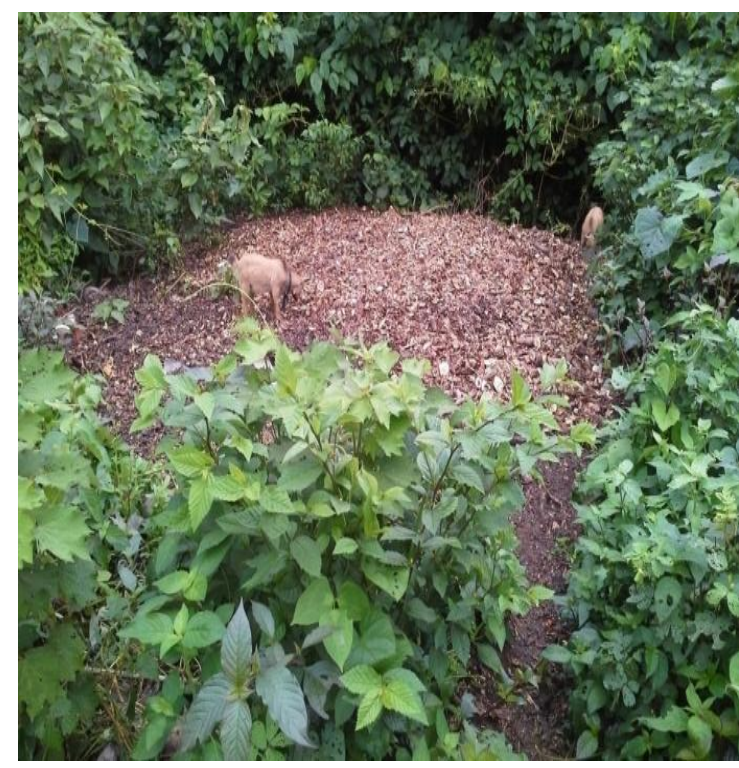

Plate1. A Typical Cassava Peel dumpsite

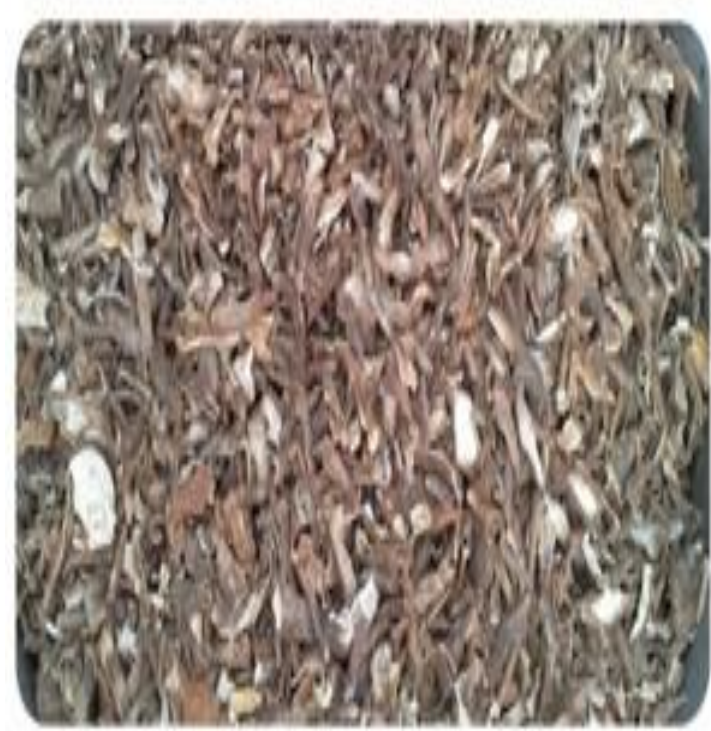

Plate2. Dried Cassava Peel sample 
Evaluation of the Structural Performance of Lateritic Soil Stabilized with Cassava Peel Ash (CPA) and Cement

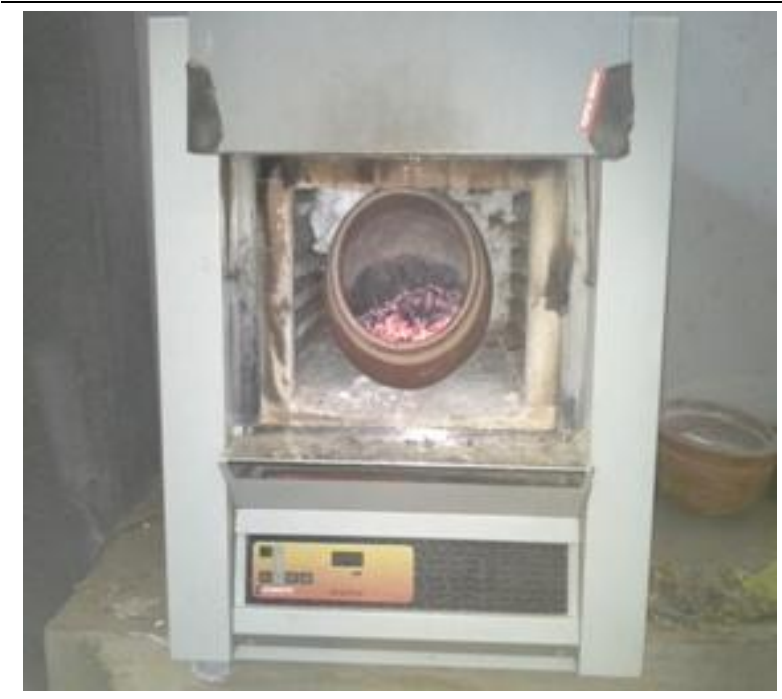

Plate3. Converting Cassava Peel to CPA (placed in earthen pot)

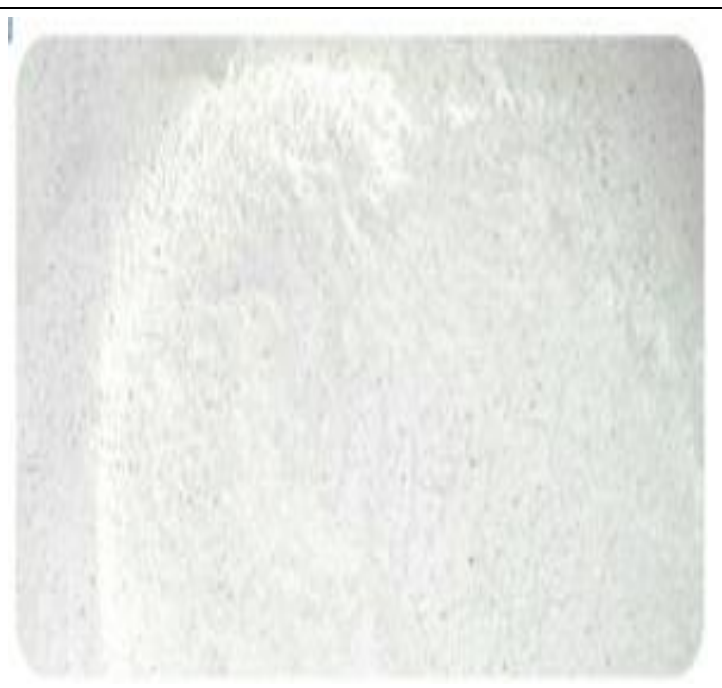

Plate4. Cassava Peel Ash sample

Table1. Result of Chemical Analysis of the CPA Sample

\begin{tabular}{|c|c|c|}
\hline $\mathbf{S} / \mathbf{N}$ & Compound & $\begin{array}{c}\text { Level of Cassava Peel Ash Oxide } \\
\text { Detected (\%) }\end{array}$ \\
\hline 1 & $\mathrm{SiO}_{2}$ & 56.81 \\
\hline 2 & $\mathrm{Fe}_{2} \mathrm{O}_{3}$ & 7.21 \\
\hline 3 & $\mathrm{Al}_{2} \mathrm{O}_{3}$ & 7.74 \\
\hline 4 & $\mathrm{CaO}$ & 6.94 \\
\hline 5 & $\mathrm{MgO}$ & 3.93 \\
\hline 6 & $\mathrm{SO}_{3}$ & 4.05 \\
\hline 7 & $\mathrm{~K}_{2} \mathrm{O}$ & 4.64 \\
\hline 8 & $\mathrm{Na}_{2} \mathrm{O}$ & 0.43 \\
\hline 9 & $\mathrm{Loss}$ on Ignition & 6.78 \\
\hline 10 & ${\mathrm{Specific} \mathrm{Gravity}_{2}}$ & 1.95 \\
\hline 11 & $\mathrm{Al}_{2} \mathrm{O}_{3}+\mathrm{Fe}_{2} \mathrm{O}_{3}$ & 14.95 \\
\hline 12 & $\mathrm{SiO}_{2}+\mathrm{Fe}_{2} \mathrm{O}_{3}+\mathrm{Al}_{2} \mathrm{O}_{3}$ & 71.76 \\
\hline
\end{tabular}

The result shows that the combined percentage of $\mathrm{SiO}_{2}+\mathrm{Fe}_{2} \mathrm{O}_{3}+\mathrm{Al}_{2} \mathrm{O}_{3}=71.76 \%$ is greater than $70 \%$ and this shows that the CPA meets the ASTM standard for a good pozzolan (ASTM C 618 \& TS 25).

The results of the preliminary tests on the lateritic soil sample are shown in Table 2.

Grading based on the LL and PI shows that the AASHTO Classification is A-7-5 Lateritic soil.

Table2. Summary of Preliminary Tests on Soil (A: 7:5)

\begin{tabular}{|c|c|}
\hline Properties & Values \\
\hline Natural Moisture Content (\%) & 15.60 \\
\hline Specific Gravity & 2.57 \\
\hline Liquid Limit (\%) & 41.40 \\
\hline Plastic Limit (\%) & 30.10 \\
\hline Plasticity Index (\%) & 11.31 \\
\hline Maximum Dry Density () & 1.81 \\
\hline Optimum Moisture Content (\%) & 15.20 \\
\hline CBR (\%) - Unsoaked & 23 \\
- Soaked & 15 \\
\hline Unconfined Compressive Strength (MN/m $\left.{ }^{2}\right)$ & 21.09 \\
\hline AASHTO Classification & A-7-5 \\
\hline Unified Classification. System classification & Clayey \\
\hline Soil Type & Pight Brown \\
\hline Color & \\
\hline
\end{tabular}


Olutaiwo A.O. \& Adanikin Ariyo

\subsubsection{Specific Gravity Test Result}

Specific Gravity $=\frac{W 2-W 1}{(W 4-W 1)-(W 3-W 2)}$

Specific Gravity $\mathrm{G}_{\mathrm{s}}$ was obtained as 2.57

This falls within the range of value for clayey soils $(2.44-2.92)$ or Kaolin $(2.47-2.92)$.

\subsubsection{Atterberg Limits Results}

The liquid and plastic limit results for soil + CPA $(0-10 \%)$ are shown in Table 3 and the corresponding graphs are shown in Fig. 2.

Table3. Atterberg Limits of Lateritic Soil + CPA $(0 \%-10 \%)$

\begin{tabular}{|c|c|c|c|c|c|c|}
\hline & $\mathbf{0 \%}$ & $\mathbf{2 \%}$ & $\mathbf{4 \%}$ & $\mathbf{6 \%}$ & $\mathbf{8 \%}$ & $\mathbf{1 0 \%}$ \\
\hline Liquid Limit & 41.40 & 42.21 & 44.43 & 52.87 & 57.67 & 58.31 \\
\hline Plastic Limit & 30.10 & 29.32 & 26.57 & 25.01 & 24.90 & 23.98 \\
\hline Plasticity Index & 11.30 & 12.89 & 17.86 & 27.86 & 32.77 & 34.33 \\
\hline
\end{tabular}

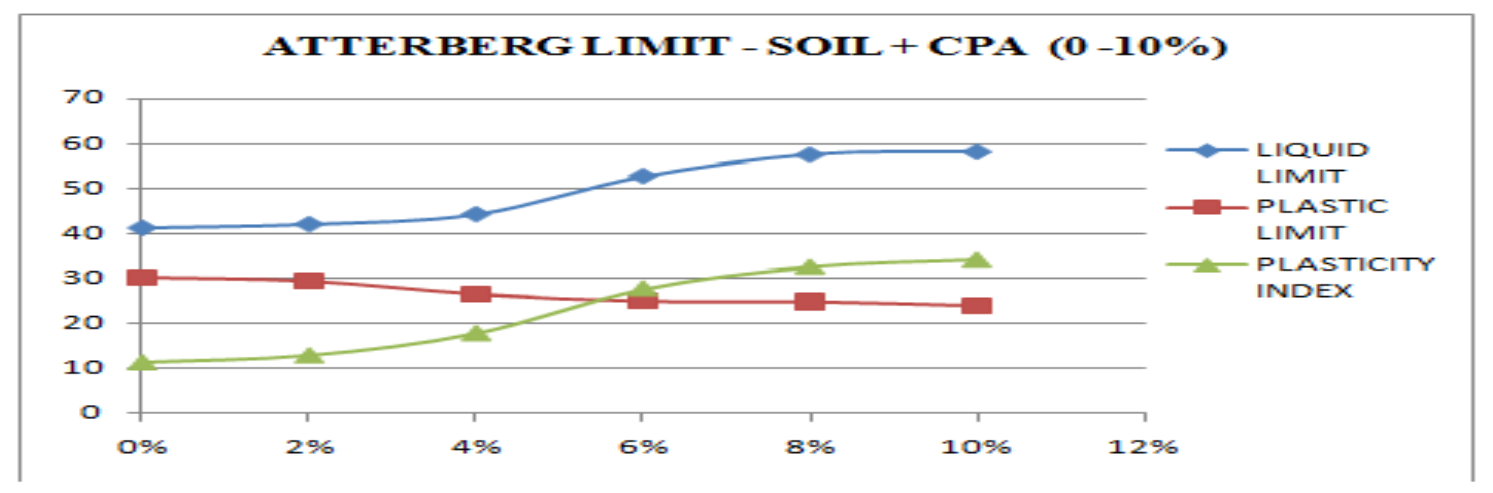

Fig2. Graphs of Atterberg Limits of Soil $+C P A(0-10 \%)$

LL - Increase in CPA introduced more pozzolanic substances from the ash that required more amount of water for hydration.

PL - Amount of soil to be flocculated decreased and the CPA incorporated the voids in the soil

The liquid and plastic limit results for soil + CPA $(0-10 \%)+5 \%$ Cement are shown in Table 4 and the corresponding graphs are shown in Fig. 3.

Table4. Atterberg Limits of Lateritic Soil + CPA $(0 \%-10 \%)+5 \%$ Cement

\begin{tabular}{|c|c|c|c|c|c|c|}
\hline & $\mathbf{0 \%}$ & $\mathbf{2 \%}$ & $\mathbf{4 \%}$ & $\mathbf{6 \%}$ & $\mathbf{8 \%}$ & $\mathbf{1 0 \%}$ \\
\hline Liquid Limit & 41.40 & 45.45 & 49.72 & 56.11 & 63.89 & 67.45 \\
\hline Plastic Limit & 30.10 & 27.12 & 26.78 & 24.34 & 22.01 & 21.33 \\
\hline Plasticity Index & 11.30 & 18.33 & 22.94 & 31.77 & 41.88 & 46.12 \\
\hline
\end{tabular}

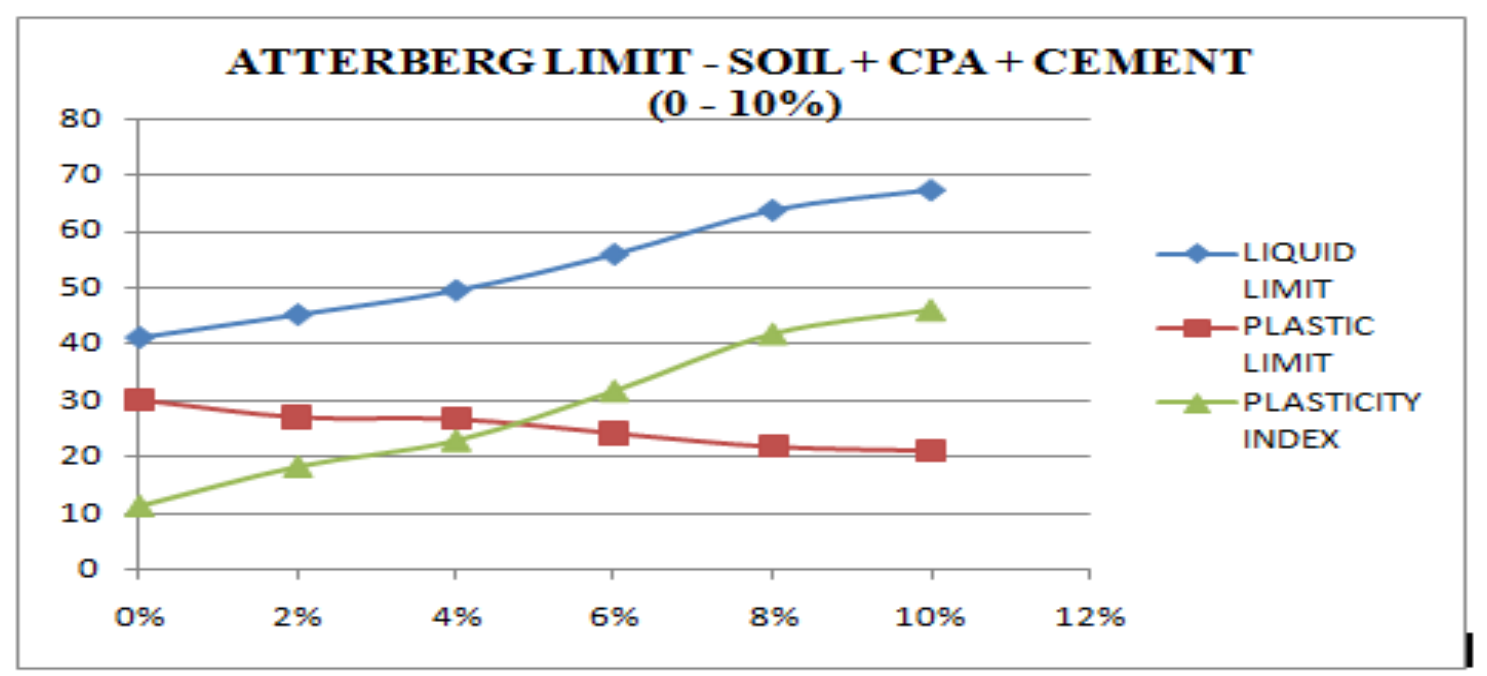

Fig3. Graphs of Atterberg Limit of Soil $+C P A(0-10 \%)+5 \%$ Cement 
There was an increase in liquid limit with increase in cassava peel ash content. The result is in agreement with the definition of liquid limit, which is the moisture content at which the soil exhibits dynamic shear strength. When an alteration occurs in the system of a soil existing in its liquid limit such that there is relative decrease in the repulsive forces, its strength increase to a specific value such that more moisture will be needed to bring the soil to its dynamic shear strength. This tended to increase the value of the liquid limit of the soil - CPA mixture from the value of $41.40 \%$ at $0 \%$ CPA content to a maximum value of $58.31 \%$ at $10 \% \mathrm{CPA}$ content.

The addition of CPA resulted in a decrease in the plastic limit of the treated soils (see Table 3 and Fig 2). This could be due to insufficient free lime content in the CPA so as to increase the plastic limit and hence the reduction. There was reduction in the plastic limit from $30.10 \%$ at $0 \%$ CPA to $23.98 \%$ at $10 \%$ CPA. For the CPA+ 5\% Cement admixture, the reduction of plastic limit was from $30.10 \%$ at $0 \% \mathrm{CPA}+5 \%$ Cement to $21.33 \%$ at $10 \% \mathrm{CPA}+5 \%$ Cement. Plasticity Index increased due to deficiency of $\mathrm{Ca}^{2+}$ which is required to replace the weakly bonded ions in the soil structure and hence, flocculation did not occur.

\subsection{Compaction Test- OMC}

The natural Optimum Moisture Content (OMC) of the sample was $15.20 \%$ with a Maximum Dry Density (MDD) of $1.81 \mathrm{~g} / \mathrm{cm}^{3}$. In the Soil + CPA sample, the addition of CPA $(0-10 \%)$ caused corresponding increase in the OMC of the soil. The corresponding values of the OMC are shown in Table 5. On addition of CPA in proportion of 2-10\%, a perpetual decrease in the value of the MDD was recorded. The Maximum Dry Density of the corresponding addition of CPA (2\%-10\%) is as shown in Table 6.

For the Soil $+\mathrm{CPA}+5 \%$ Cement, the value of the $\mathrm{OMC}$ at $0-10 \%$ increased with corresponding decrease in the values of the MDD as listed in Table 5 and 6.

Table5. Results of OMC with Variation of CPA and Cement

\begin{tabular}{|c|c|c|}
\hline $\begin{array}{c}\text { CPA Variation } \\
(\boldsymbol{\%})\end{array}$ & $\begin{array}{c}\text { OMC of Soil + CPA } \\
(\boldsymbol{\%})\end{array}$ & $\begin{array}{c}\text { OMC of Soil + CPA + 5\% Cement } \\
(\boldsymbol{\%})\end{array}$ \\
\hline 0 & 15.20 & 15.20 \\
\hline 2 & 15.20 & 16.10 \\
\hline 4 & 16.13 & 16.90 \\
\hline 6 & 16.48 & 16.80 \\
\hline 8 & 16.56 & 16.80 \\
\hline 10 & 16.92 & 17.00 \\
\hline
\end{tabular}

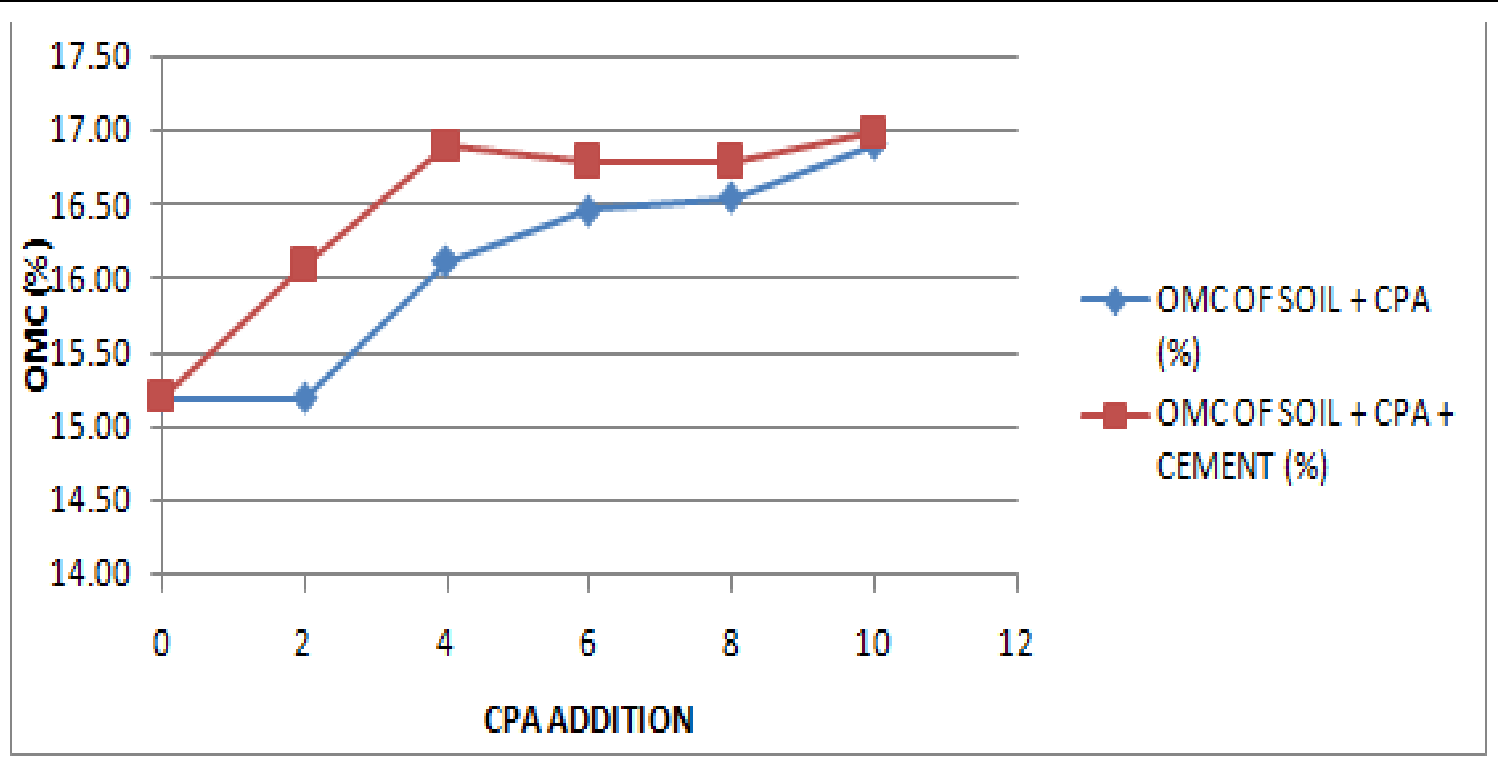

Fig4. Graphs of OMC of Samples with CPA $(0-10 \%)+5 \%$ Cement

The increase in OMC was due to the addition CPA + Cement, which decreased the quantity of free silt and clay fraction and coarser materials with larger surface areas were formed (these processes need water to take place). 
Olutaiwo A.O. \& Adanikin Ariyo

\subsection{Compaction Test - MDD}

Table6. Summary of MDD with Variation of $C P A$

\begin{tabular}{|c|c|c|}
\hline $\begin{array}{c}\text { CPA Variation } \\
(\boldsymbol{\%})\end{array}$ & $\begin{array}{c}\text { MDD of Soil + CPA } \\
\left(\mathbf{g} / \mathbf{c m}^{\mathbf{3}}\right)\end{array}$ & $\begin{array}{c}\text { MDD of Soil + CPA + 5\% Cement } \\
\left(\mathbf{g} / \mathbf{c m}^{\mathbf{}}\right)\end{array}$ \\
\hline 0 & 1.80 & 1.80 \\
\hline 2 & 1.82 & 1.80 \\
\hline 4 & 1.81 & 1.79 \\
\hline 6 & 1.79 & 1.78 \\
\hline 8 & 1.73 & 1.73 \\
\hline 10 & 1.70 & 1.70 \\
\hline
\end{tabular}

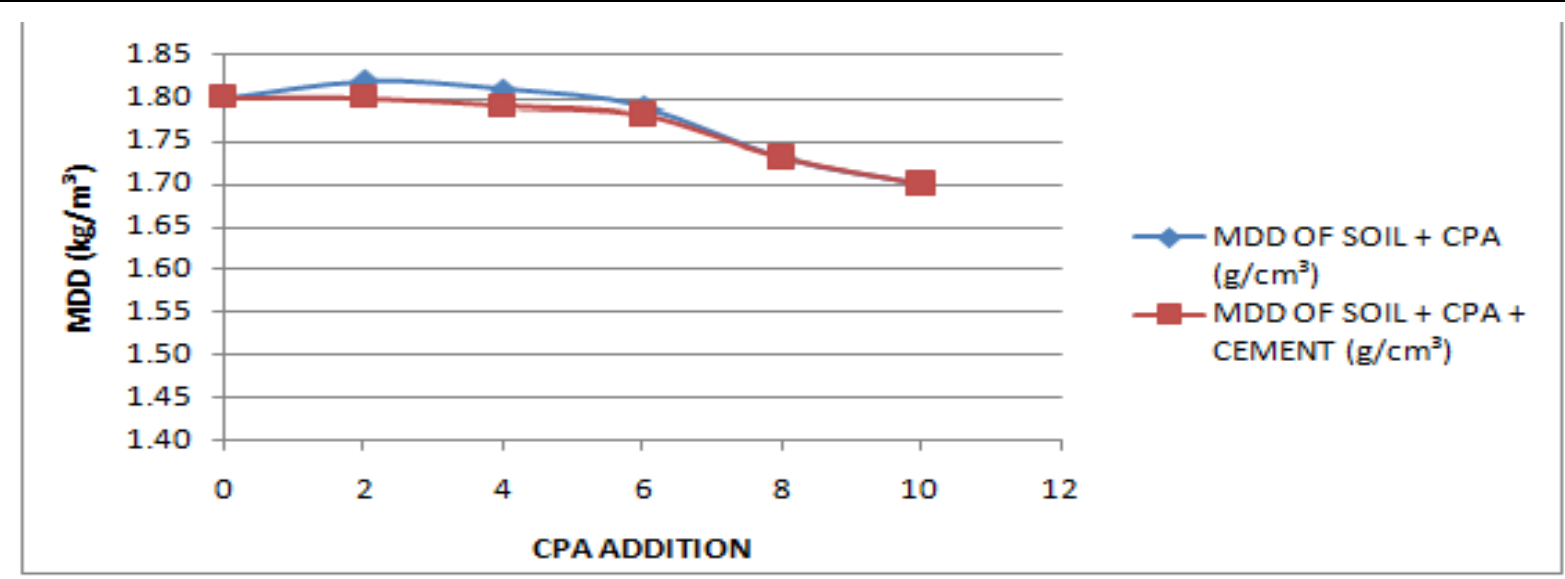

Fig5. Graph of MDD of Samples with CPA (0-10\%)+ 5\% Cement

The decrease in the MDD may be attributed to the replacement of portion of the lateritic soil by the CPA which has relatively lower specific gravity (1.95) and the Cement-CPA of specific gravity of 2.32 compared to the soil (2.57). It may also be attributed to coating of the soil by the CPA which result to large particles with larger voids and hence less density. But the presence of cement in most soil types generally increases the MDD.

\subsection{C.B.R. Tests - Unsoaked and Soaked}

The variation of soaked and unsoaked California Bearing Ratio (CBR) for lateritic soil treated with CPA only and CPA + Cement was analyzed and the results are as shown in Tables 7 and 8 . The soaked CBR values of the treated soil increased from $15 \%$ for the natural soil to $22 \%$ for $8 \%$ and decreased to $20 \%$ at $10 \%$ CPA.

Table7. Table of Unsoaked CBR for Soil + CPA and Soil + CPA + 5\% Cement

\begin{tabular}{|c|c|c|c|c|c|c|}
\hline & \multicolumn{7}{|c|}{ UNSOAKED CBR } \\
\hline CPA increment & $\mathbf{0 \%}$ & $\mathbf{2 \%}$ & $\mathbf{4 \%}$ & $\mathbf{6 \%}$ & $\mathbf{8 \%}$ & $\mathbf{1 0 \%}$ \\
\hline Soil +CPA & 23 & 23 & 24 & 26 & 29 & 33 \\
\hline Soil +CPA+ Cement & 23 & 44 & 45 & 62 & 68 & 76 \\
\hline
\end{tabular}

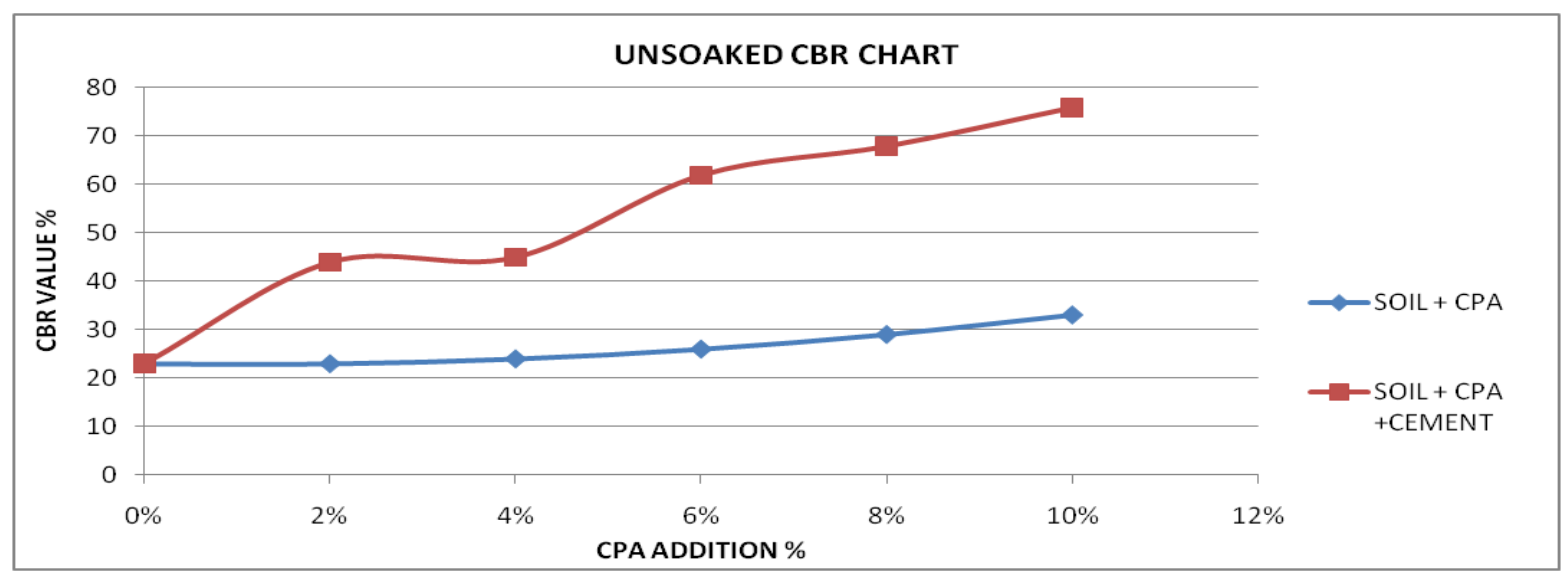

Fig6. Graphs of Unsoaked CBR for Soil + CPA and Soil +CPA + 5\% Cement 
Evaluation of the Structural Performance of Lateritic Soil Stabilized with Cassava Peel Ash (CPA) and Cement

The unsoaked CBR values also increased but the increase for Soil+ CPA + Cement was greater compared to that of Soil + CPA

Table8. Results of Soaked CBR for Soil $+C P A$ and Soil $+C P A+5 \%$ Cement

\begin{tabular}{|c|c|c|c|c|c|c|}
\hline & \multicolumn{9}{|c|}{ SOAKED CBR } & $\mathbf{1 0 \%}$ \\
\cline { 2 - 7 } & $\mathbf{0 \%}$ & $\mathbf{2 \%}$ & $\mathbf{4 \%}$ & $\mathbf{6 \%}$ & $\mathbf{8 \%}$ & $\mathbf{1 0 \%}$ \\
\hline Soil +CPA & 15 & 20 & 21 & 22 & 22 & 20 \\
\hline Soil +CPA+ Cement & 15 & 50 & 52 & 68 & 74 & 84 \\
\hline
\end{tabular}

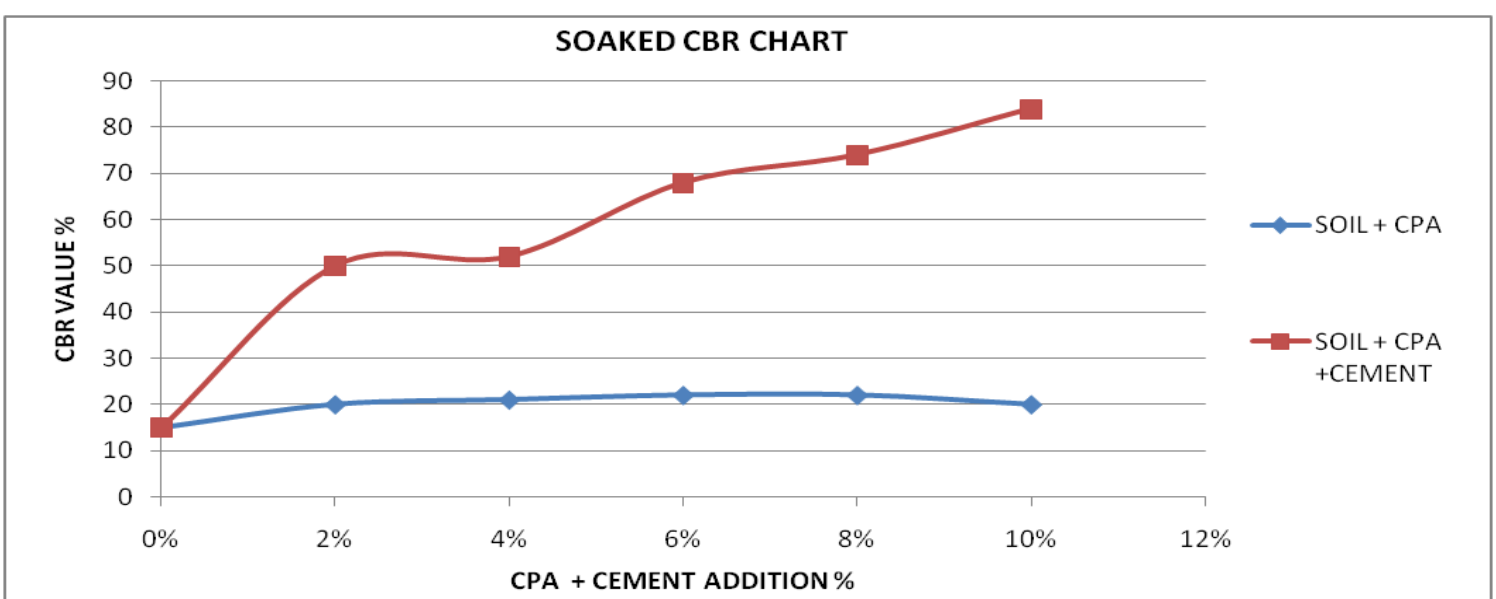

Fig7. Graphs of soaked CBR for Soil + CPA and Soil $+C P A+5 \%$ Cement

The significant increase in soaked CBR over the unsoaked is probably due to the combined effect of cement in the admixed Soil + CPA + Cement which reflects the hydrating effect of cement in the presence of water, which leads to increase in strength.

\subsection{Unconfined Compression Strength (UCS) Test}

The UCS results with variation of CPA from $0 \%$ to $10 \%$ and for CPA variation $+5 \%$ Cement are as shown in Table 9 and Figure 8. It is observed that the UCS for the soil and CPA admixture increased from $21.09 \mathrm{KN} / \mathrm{m} 3$ (for the natural soil) to $32.80 \mathrm{KN} / \mathrm{m} 3$ at $10 \% \mathrm{CPA}$ addition.

The UCS values increase with subsequent addition of CPA $+5 \%$ Cement to its maximum at between $8 \% \mathrm{CPA}+5 \%$ Cement after which it drops at 10\% CPA+5\% Cement.

Table9. Table of UCS Values of Soil + CPA And Soil + CPA + 5\% Cement

\begin{tabular}{|c|c|c|c|c|c|c|}
\hline & $\mathbf{0 \%}$ & $\mathbf{2 \%}$ & $\mathbf{4 \%}$ & $\mathbf{6 \%}$ & $\mathbf{8 \%}$ & $\mathbf{1 0 \%}$ \\
\hline Soil + CPA & 21.09 & 22.01 & 25.81 & 26.69 & 29.86 & 32.80 \\
\hline $\begin{array}{c}\text { Soil + CPA } \\
\text { +5\% Cement }\end{array}$ & 21.09 & 25.96 & 31.76 & 34.47 & 37.21 & 35.95 \\
\hline
\end{tabular}

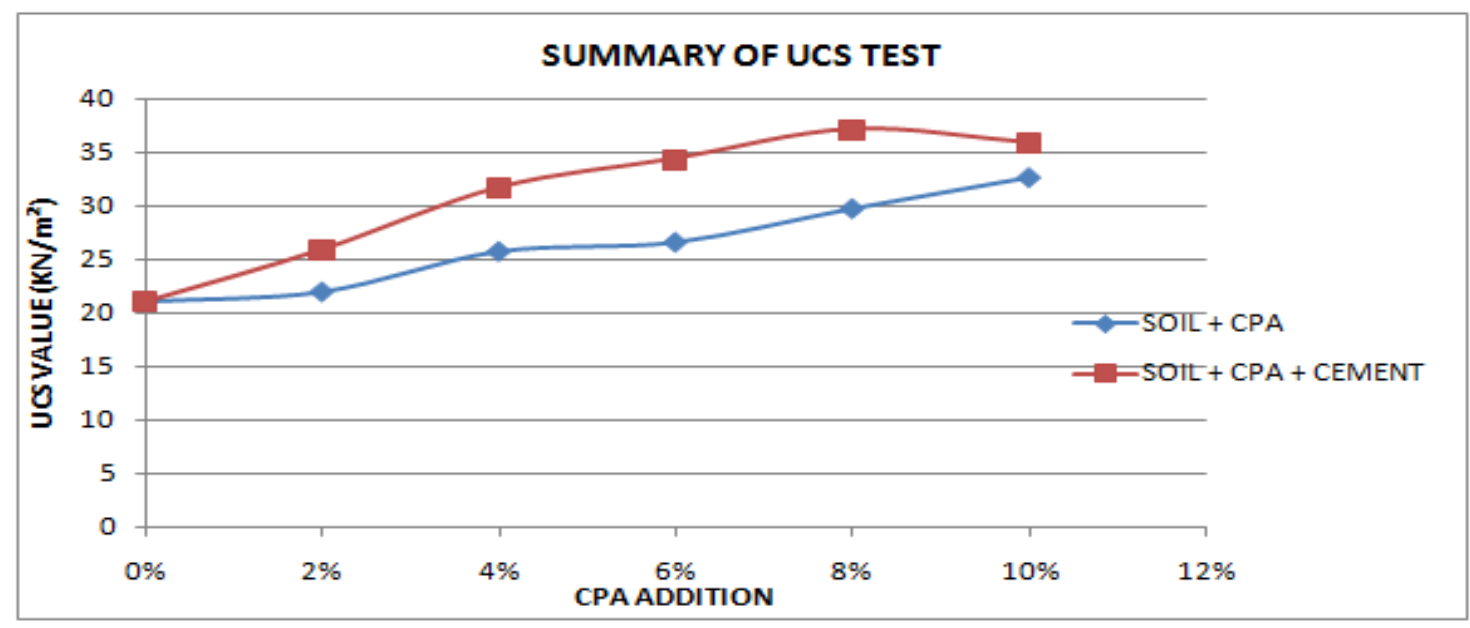

Fig8. Graphs of UCS Tests 
The increase in the UCS is attributed to the formation of cementitious compounds between the $\mathrm{CaOH}$ present in the soil and CPA and the pozzolans present in the CPA+ Cement admixture.

\section{CONClusion}

The engineering properties of the lateritic soil improved when stabilized with Cement and Cassava Peel Ash compared to when it was stabilized with Cassava Peel Ash alone. The soil classification according to AASHTO was A-7-5 at 0\% CPA changed to A-2-7 at 10\% CPA indicating a fairly better and improved soil. The OMC of the CPA stabilized soil increased while its MDD decreases. The CBR and UCS values increased for the lateritic soil stabilized with CPA.

The stabilized lateritic soil with CPA will be most suitable for use as fill materials while the stabilized admixed lateritic CPA $+5 \%$ Cement soil will be suitable for use as base courses. CPA, when used as an alternative or as a partial replacement of cement in stabilizing Lateritic soils, can help reduce the cost of road construction materials and help solve disposal problems associated with Cassava Peels as an agricultural waste.

\section{RECOMMENDATION}

In the light of the positive effects of the Cassava Peel Ash as a pozzolana, it is recommended that CPA be produced in commercial quantity in its pure form or as a CPA-cement blend and used as a stabilizing agent for road pavement construction especially for low trafficked or rural roads.

\section{REFERENCES}

AASHTO (1986): "Standard Specifications for Transportation Materials and Method of Sampling and Testing". American Association of State Highway and Transportation Officials, Washington, DC, USA.

BS. 1377 (1990): "Methods of Testing Soil for Civil Engineering Purposes". British Standards Institute, London, England

Chmeisse, C. (1992): "Soil Stabilization Using Some Pozzolanic Industrial and Agricultural Products" Doctor of Philosophy thesis, Department of Civil and Mining Engineering, University of Wollongong. Accessed at: http//ro.uow.edu.au/thesis/1268 at October 2015.

Edeh, J., Tyav, S., and Osinubi, K. (2014): “Cassava Peel Ash Stabilized Lateritic Soil as Highway Pavement Material". Pavement Materials, Structures, and Performance: pp. 375-382. doi: 10.1061/9780784413418.037

FAO (2013): "Save and Grow: Cassava, A guide to sustainable production intensification", Food and Agriculture Organization of the United Nations, Rome. pp.1- 129.

Food Safety Network (2005): “What is Cassava?" Retrieved from http://foodsafety.ksu.edu/articles /533/cassava_factsheet.pdf. http://en.wikipedia.org/wiki/Pozzon

Lambe, T.W and Whitman. R. (1979): "Soil mechanics", SI version, John Wiley and Sons Inc., New York.

M. A Salau, E.E Ikponmwosa, and K.A Olonade (2012): "Structural Strength Characteristics of Cement-Cassava Peel Ash Blended Concrete", Civil and Environmental Research ISSN 22221719 (Paper) ISSN 2222-2863 (Online) Vol 2, No.10,

Garber, N. J and Hoel, L. A. (2000): "Traffic and Highway Engineering", 2nd ed. Brooks/Cole Publishing Company, London, 481- 492, 927- 930.

Nigerian General Specifications (1997): "Roads and Bridge Works". Federal Ministry of Works, Lagos, Nigeria.

Olonade, K.A. (2014) "Characterization of Cassava Peel Ash (CPA) As Pozzolan in Concrete" Doctor of Philosophy thesis, Department of Civil and Environmental Engineering, University of Lagos.

Olugbenga O. Amu et. al. (2010) "Characteristics of Bamboo Leaf Ash Stabilization on Lateritic Soil". Highway International Journal of Engineering and Technology Vol.2.

Oluremi, J.R., S.I. Adedokun, and O.M. Osuolale. (2012). "Effect of Coconut Husk Ash on the Geotechnical Properties of Poor Lateritic Soil". Pacific Journal of Science and Technology. 13(2):499-507.

Salau, M.A. and Olonade, K.A. "Pozzolanic Potentials of Cassava Peel Ash". Journal of Engineering Research, No.6, March 2011, pp. 10-20. 
Evaluation of the Structural Performance of Lateritic Soil Stabilized with Cassava Peel Ash (CPA) and Cement

AUTHORS' BIOGRAPHY

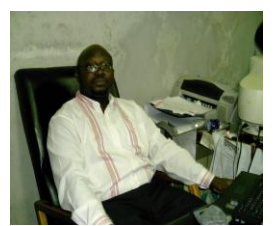

Dr. A. O. Olutaiwo, is a senior lecturer in the Department of Civil \& Environmental Engineering, University of Lagos, Nigeria. He specializes in Highway, Traffic and Transportation Engineering.

Engr. Ariyo Adanikin, is a M.Sc. holder of Highway and Traffic Engineering. He is also a registered and practicing civil / structural engineer. 